\title{
Spatio-temporal evolution of Mesoproterozoic magmatism in NE Australia: A revised tectonic model for final Nuna assembly
}

\author{
SILVIA VOLANTE ${ }^{1,2}$, WILLIAM COLLINS ${ }^{1}$, VITOR \\ BARROTE $^{2,3}$, ADAM NORDSVAN ${ }^{1,4}$, ZHENG-XIANG LI $^{1}$, \\ AMAURY POURTEAU ${ }^{1}$ AND SIMON BEAMS ${ }^{5}$ \\ ${ }^{1}$ Curtin University \\ ${ }^{2}$ Ruhr-Universität Bochum \\ ${ }^{3}$ Monash University \\ ${ }^{4}$ University of Hong Kong \\ ${ }^{5}$ Terra Search Pty Ltd \\ Presenting Author: silvia.volante@ruhr-uni-bochum.de
}

The tectonic forces that drove the 1550-1490 Ma granitic magmatism c. 50 million years after the final assembly of the Proterozoic supercontinent Nuna in NE Australia have remained elusive. Collision between the eastern Australian proto-continent (Mount Isa Inlier, MTI) and the western Laurentian Georgetown Inlier (GTI) occurred at $1600 \mathrm{Ma}$ [1], and was associated with a west-dipping subduction, with the MTI (NE Australia) as the upper plate and the GTI (NW Laurentia) as the lower plate. Dominant S- and I- type magmatism is confined to the lower plate (GTI), while I- and A-type granites intruded further west (inboard) the Australian upper plate (MTI).

Structural studies in the GTI showed that the collisional event involved WNW-ESE (D1/M1) shortening at c. $1600 \mathrm{Ma}$, followed by NW-SE directed extension (D2/M2) at c. $1550 \mathrm{Ma}$ [2]. During the D2 extensional stage, a crustal-scale, westdipping detachment fault system juxtaposed middle- to lowercrustal levels of the GTI associated with the generation of voluminous, $1550 \mathrm{Ma}$ S-type granitic magmas, against greenschist facies upper crustal rocks. From the GTI, an inboard (westward) transition of S-I-A granitic magmatism was accompanied by a westward younging of these plutons, from $1550 \mathrm{Ma}$ until $1490 \mathrm{Ma}$. This transition from relatively hydrous (S-type) granites in the east to drier (A-type) granites to the west is also supported by increasing zircon saturation temperatures. Recent Lu-Hf analyses of zircon and new in-situ Sm-Nd analyses of monazite in granites show an increasing radiogenic composition trend from the east (GTI) to the west (MTI), which reflects a concomitant westward increase in mantle input. Combined, these features suggest a spatio-temporal evolution of hotter and drier crustal conditions inboard (westward) associated with a progressive lithospheric extension. Classical Phanerozoic extensional collapse, upper plate delamination, and Aegean-style subduction-rollback tectonic models do not account for all of the features of this post-collisional magmatic record. Rather a hybrid tectonic setting between fast-hard Indian and slow-soft Mediterranean collision better explains the attributes of the final Nuna suturing in Mesoproterozoic NE Australia.

References

Pourteau et al. (2020). EPSL, 550: 116548

Volante et al., 2020. Tectonics, 39 (10): e2020TC006162 